\title{
ALIMENTOS, ENERGIA E MATÉRIAS-PRIMAS: INOVAÇÃO NO APROVEITAMENTO DE RECURSOS NATURAIS
}

O Brasil é um dos vilões do atual processo de mudanças climáticas, principalmente devido às vultosas emissões de gás carbônico causadas pela queima de florestas. Essa situação evidencia que, infelizmente, uma parte da população brasileira trata a floresta como um inimigo que deve ser destruído e não como uma fonte de riqueza e bem-estar que deve ser preservada, com empenho e energia. Lamentavelmente, esse é apenas um aspecto de uma situação mais ampla: não praticamos, no Brasil, um bom padrão de aproveitamento dos nossos recursos naturais.

Temos casos importantes de produção e aproveitamento inteligente da biomassa, com destaque para a cana-de-açúcar. Esta é uma cultura oriunda da Índia, introduzida há cerca de cinco séculos no Brasil. Seu plantio em algumas áreas já data de mais de quatrocentos anos e em regiões tradicionais do estado de São Paulo, como Piracicaba, tem sido feito com sucesso desde o século 18. A cana é, hoje, fonte de alimentos, combustível e de materiais. Ela gera matérias-primas para a produção de aminoácidos e proteínas, vitaminas, papel, termoplásticos, ceras e solventes ambientalmente aceitáveis. Além disso, a capacidade de geração de eletricidade nas usinas de açúcar e álcool ligadas à rede elétrica chegou a 1,5 gigawatts em 2007, ou seja, mais do que um décimo de Itaipu, mas com investimentos muitíssimo menores que os de Itaipu. Os excessos de bagaço de cana são ainda usados por muitas outras indústrias como fonte de energia térmica, o que permite a estas apresentar uma baixa pegada de carbono.

Infelizmente, temos casos opostos e o mais recente é o do biodiesel de mamona. O óleo de mamona é uma matéria-prima valiosa para a indústria química, mas erros de política pública transformaram-no em um fracasso na produção de biodiesel. A pretendida geração de renda para agricultores familiares, que poderia ter sido obtida fazendo o Brasil retornar à posição de maior produtor de óleo de mamona do mundo não ocorreu, por uma falta de visão de conjunto e de informação.

A Sociedade Brasileira de Química tem tido um papel importante na formulação de planos e políticas de desenvolvimento da química brasileira, em todos os seus aspectos, ao longo da sua existência. $\mathrm{O}$ momento atual exige, mais do que em qualquer outro no passado, que a SBQ se aplique a esse tipo de atividade, mobilizando para isso toda a energia e a criatividade de seus membros.

Uma tal missão exige diagnósticos cuidadosos, que embasem planos com objetivos consequentes e estratégias efetivas e nos permitam atingir metas desejáveis e saudavelmente ambiciosas. Este número de Química Nova contribui para isso, publicando artigos sobre o aproveitamento de recursos naturais, transmitindo informações relevantes e discutindo perspectivas de inovação. Os editores agradecem aos autores que foram convidados e submeteram artigos, bem como aos revisores que contribuíram com críticas, correções e sugestões. Estamos todos cientes de que dificilmente algum destes artigos atingirá índices de impacto importantes e estamos todos certos de que nenhum deles será uma contribuição significativa a qualquer indicador de produtividade dos autores, revisores e editores. Entretanto, estamos certos de que eles serão úteis para uma grande população de estudantes, pesquisadores e profissionais da Química, fornecendo-lhes dados e compartilhando idéias, experiências e esperanças. Cremos que assim se faz política de desenvolvimento científico e tecnológico, voltada para o bem comum.

Fernando Galembeck - Editor Convidado Vera L. Pardini - Editora de QN 